\title{
Effects of Hizikia fusiforme Fractions on Melanin Synthesis in B16F10 Melanoma Cells
}

\author{
Eun Ok Choi ${ }^{1,2}$, Hyang Suk Kim², Min Ho Han ${ }^{3}$, Yung Hyun Choi ${ }^{2,3,4}$, Cheol Park, Byung Woo Kim ${ }^{4,6}$ \\ and Hye Jin Hwang ${ }^{4,7}$ *

\begin{abstract}
${ }^{2}$ Anti-aging Research Center, ${ }^{3}$ Department of Oriental Medicine, ${ }^{4}$ Blue-Bio Industry Regional Innovation Center, ${ }^{5}$ Department of Life Science and Techndogy, ${ }^{6}$ Department of Molecular Biology, ${ }^{7}$ Department of Food \& Nutrition, Dong-Eui University, Busan 614-714, Korea
\end{abstract} \\ ${ }^{1}$ Department of Food \& Nutrition, Pusan National University, Busan 609-735, Korea
}

Received October 21, 2013 / Revised November 18, 2013 / Accepted December 3, 2013

\begin{abstract}
The objective of this study was to evaluate the anti-melanogenic effects of Hizikia fusiforme (HF) fractions in a-melanocyte stimulating hormone-induced B16F10 mouse melanoma cells. Ethanol extractions of Hizikia fusiforme (EEHF) were subjected to fraction by using dichloromethane (CFHF), ethyl acetate (EAFHF), butanol (BFHF), and water (WFHF). EEHF, CFHF, and EAFHF inhibited tyrosinase activity and melanin synthesis in B16F10 mouse melanoma cells in a dose-dependent manner. The melanin contents were inhibited by $40.5 \%$ and $33.2 \%$ in response to treatment with $50 \mu \mathrm{g} / \mathrm{ml}$ of EEHF and CFHF, respectively. In addition, tyrosinase activities showed a $53.3 \%$ and $54.1 \%$ reduction in treatment with $50 \mathrm{\mu g} / \mathrm{ml}$ of EEHF and CFHF. Western blotting analysis showed that EEHF, CFHF, and EAFHF inhibited tyrosinase, TRP-1, TRP-2, and MITF expression in a dose-dependent manner. In conclusion, these findings indicate that ethanol and dichloromethane fractions of Hizikia fusiforme, which inhibit melanin synthesis and tyrosinase activity, are effective skin-whitening agents.
\end{abstract}

Key words : Hizikia fusiforme, melanogenesis, tyrosinase

\section{서 론}

표피의 기저층에 존재하는 멜라닌은 인간의 피부색을 결정 짓는데 가장 중요한 역할을 하며, 태양 광선으로부터 들어오 는 자외선을 차단하는 색소이다. 과도하게 합성되거나, 노화 등에 의해 피부의 생리기능이 떨어지면 피부 표면에 침착되어 기미, 주근깨 및 다양한 색소로 나타난다 $[1,9]$. 멜라닌 합성은 tyrosinase, tyrosinase related protein-1 (TRP-1)과 tyrosinase related protein-2 (TRP-2), cyclic adenosine monophosphate (cAMP) 유도 물질인 adrenocorticotropic hormone (ACTH), forskolin과 a-melanocyte stimulating hormone (a-MSH) 등 에 의해서 조절된다[3, 14, 22].

최근 사람들이 미용과 건강에 관심이 증가하면서 미백 기능 성 소재에 관한 연구가 다양하게 이루어지고 있으며, 특히 안 정적이고 효과적인 소재인 천연물을 이용한 연구가 활발히 진행되고 있다. 특히 해조류인 감태, 곰피, 미역 등 $[6,12,19]$ 의 melanin 합성과정과 tyrosinase 저해효과에 대한 연구와 곰취,

\footnotetext{
*Corresponding author

Tel : +82-51-890-1594, Fax : +82-51-890-2646

E-mail : hhj2001@deu.ac.kr

This is an Open-Access article distributed under the terms of the Creative Commons Attribution Non-Commercial License (http://creativecommons.org/licenses/by-nc/3.0) which permits unrestricted non-commercial use, distribution, and reproduction in any medium, provided the original work is properly cited.
}

미역취 등의 복합 추출물[11], 조릿대[24] 등 약용작물의 미백 효과에 대한 연구가 보고되고 있다.

본 연구에 사용된 톳(Hizikia fusiforme)은 갈조류 모자반과 에 속하며 20 100 cm까지 성장하는 다년생 해조류로, 평균 수면에서 저조선 약 $30 \mathrm{~cm}$ 위쪽의 조간대 하부에 서식한다. 식용해조류는 육상식물과는 다른 환경으로 인하여 생체 내 2차 대사산물의 화학구조가 매우 독특하며, 해양천연물의 2차 대사산물은 생리기능이나 생태계의 제어에 매우 중요한 생리 활성 물질을 함유하고 있다[17]. 톳은 우수한 식이섬유소의 공 급원일 뿐만 아니라 혈액응고작용, 면역증강작용 등의 기능성 이 있는 것으로 알려진 중성다당류인 라미나란(laminaran)과 함황산성 다당류인 푸코이단(fucoidan)이 다량 함유되어 있 다. 미역, 다시마, 톳 등의 갈조류 성분의 새로운 생리활성 성 분으로 각광을 받고 있는 푸코이단은 천연 미백물질로서의 가능성이 매우 높은 물질로 밝혀지고 있다[15]. 또한 해조류는 소화율이 낮아서 열량원으로서의 가치는 적지만 포만감과 통 변을 조절하는 효과[16] 뿐 만 아니라 면역력 증강[18], 항암[7, 13] 등의 효과가 보고되고 있다. 게다가 해조류의 식이성 섬유 소는 항산화제, 돌연변이 억제 및 혈액응고 저해 효과, 항암 효과와 같은 중요한 기능성을 보여주고, 인체에서의 지방대사 완화에 중요한 역할을 하는 것으로 보고되어 있다[21]. 이와 같이 톳에 대한 연구는 최근에 많이 이루어지고 있으나 미백 효과에 대한 연구는 아직 미비한 실정이다.

따라서 본 연구에서는 톳 분획물의 미백 효능을 알아보기 위하여 B16F10 mouse melanoma cell에서 톳 분획물에 의한 
tyrosinase 활성 및 멜라닌 형성 저해 효과, 그리고 TRP-1, TRP-2, MITF, tyrosinase 등과 같은 melanogenesis 관련 유전 자 발현에 어떠한 변화가 유발되었는지를 조사하였다.

\section{재료 및 방법}

\section{톳 분획물의 제조}

본 실험에 사용된 톳은 기장군에서 채취하여 흐르는 물로 24시간 동안 세척하여 염분과 불순물을 제거하고 깨끗한 물로 수회 세척한 후 그늘에서 건조시켜 사용하였다. 건조 된 톳 $2 \mathrm{~kg}$ 을 $80 \%$ 에탄올에 24 시간 동안 침지시킨 후 환류 냉각시키 면서 $80^{\circ} \mathrm{C}$ 수욕상에서 3 시간씩 3 회 반복 추출한 후 감압 추출 농축장치(EYELA, Japan)로 에탄올 추출물(69.4 g)을 얻었다. 다음으로 Fig. 1과 같이 에탄올 추출물(ethanol extract of Hizikia fusiforme, EEHF)을 증류수에 현탁하고, 분 액깔때기에 서 dichloromethane (CFHF), ethyl acetate (EAFHF), butanol (BFHF), water (WFHF)를 순차적으로 계층 분획한 뒤 여과 후 회전진공농축기로 $45^{\circ} \mathrm{C}$ 에서 감압 농축하여 각각의 분획물 을 얻었다.

\section{시약 및 항체}

단백질 분석을 위하여 사용된 MITF, TRP1, TRP2, tyrosinase 및 actin 항체는 Santa Cruz Biotechnology Inc. (Santa Cruz, CA, USA) 및 Cell Signaling Technology (Beverly, Ma, USA)에서 구입하였다. Immunoblotting을 위해 2차 항체로 사 용된 peroxidase-labeled donkey anti-rabbit 및 peroxidase-labeled sheep anti-mouse immunoglobulin 은 Amersham Life Science Corp. (Arlington Heights, IL, USA)에서 구입하였다. a-Melanocyte stimulating hormone (a-MSH)과 L-DOPA는 Sigma-Aldrich (St. Luis, MO, USA)에서 구입하여 사용하였다.

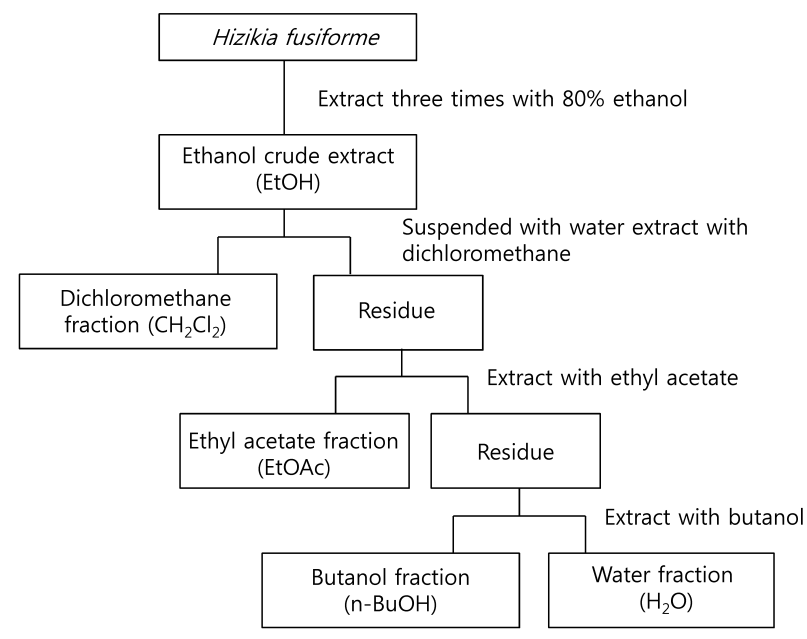

Fig. 1. Fractionation procedure of Hizikia fusiforme fractions were separate by separatory funnel.

\section{세포주 및 세포 배양}

한국 세포주은행에서 B16F10 mouse melanoma cell을 분양 받아 10\% FBS (fetal bovine serum, WELGENE, Daegu, Korea) 와 $1 \%$ penicillin-streptomycin (Gibco BRL)이 첨가된 DMEM (WELGENE, Daegu, Korea)을 사용하여 $37^{\circ} \mathrm{C}, 5 \% \mathrm{CO}_{2}$ 조건 하에서 배양하였다. 세포수의 증식에 따른 과밀도 현상을 해 소하기 위하여 배양한 B16F10 세포를 trypsin (Hyclone, USA) 을 이용하여 적정수의 세포를 유지하였다.

\section{세포생존능의 측정}

세포 배양용 6 well plate에 B16F10 melanoma 세포를 $3 \times 10^{4} / \mathrm{ml}$ 로 분주하여 톳 추출물을 각 well 당 적정농도로 처 리하였다. 72 시간 후 희석된 $0.5 \mathrm{mg} / \mathrm{ml}$ 농도의 tetrazolium bromide salt (MTT, Amresco, Solon, OH, USA)를 $200 \mu$ 씩 분주하고 2시간 동안 $\mathrm{CO}_{2}$ incubator에서 배양시킨 다음 배지 와 MTT 시약을 깨끗하게 제거하고 $\mathrm{DMSO}$ 를 $2 \mathrm{ml}$ 씩 분주하 여 well에 생성된 formazon을 모두 녹인 후 96 well plate에 200 lㅣ씩 옮겨서 ELISA reader (Molecular Devices, Sunnyvale, $\mathrm{CA}, \mathrm{USA})$ 로 $540 \mathrm{~nm}$ 에서 흡광도를 측정하였다. 각 세포에 대 한 독성은 각각의 대조군의 평균 흡광도 값을 구하여 평균 흡광도 값에 대한 백분율로 나타내었다.

\section{$\mathrm{B} 16 \mathrm{~F} 10$ 세포 내의 멜라닌 생성량 측정}

B16F10 세포에 a-melanocyte stimulating hormone (a$\mathrm{MSH})$ 와 톳 분획물을 함께 처리하여 3 일간 배양하고 세포를 수거하여 phosphate-buffered saline (PBS)로 2번 세척하였다. 그 후에 $10 \%$ dimethylsulfoxide (DMSO, Ameresco, Solon, Ohio, USA)가 함유된 $1 \mathrm{~N} \mathrm{NaOH}$ 를 적정량 넣고 $80^{\circ} \mathrm{C}$ 에서 1시 간 반응시킨 후 ELISA reader (Molecular Devices, Sunnyvale, $\mathrm{CA}, \mathrm{USA})$ 로 $475 \mathrm{~nm}$ 에서 흡광도를 측정하였다.

\section{$\mathrm{B} 16 \mathrm{~F} 10$ 세포 내의 tyrosinase 활성 측정}

$\mathrm{B} 16 \mathrm{~F} 10$ 세포에 $\mathrm{a}-\mathrm{MSH}$ 와 톳 분획물을 함께 처리하여 3일간 배양하고 세포를 수거하여 lysis buffer ( $1 \%$ Triton X-100, 0.1 $\mathrm{M} \mathrm{PMSF)}$ 를 첨가하여 1 시간 $4^{\circ} \mathrm{C}$ 에서 반응시켜 세포들을 용해 시킨 후 원심 분리하여 상층액을 수집하였다. 수집한 단백질 을 정량한 후 L-ihydroxyphenylanine (DOPA, $\mathrm{mg} / \mathrm{ml}$ )을 첨 가한 뒤 $37^{\circ} \mathrm{C}$ 에서 반응시키고 흡광도의 변화를 1 시간 동안 관찰하면서 $420 \mathrm{~nm}$ 에서 흡광도를 측정하였다.

\section{Western blot analysis에 의한 단백질 발현의 분석}

동일한 방법으로 준비된 B16F10 mouse melanoma cell에 적당량의 lysis buffer ( $1 \%$ Triton X-100, 0.1M PMSF)를 첨가하 여 $4{ }^{\circ} \mathrm{C}$ 에서 1 시간 동안 반응시킨 후, $14,000 \mathrm{rpm}$ 으로 30 분간 원심분리하여 상층액에 있는 총 단백질을 분리하였다. 상층액 의 단백질 농도는 Bio-Rad 단백질 정량 시약(Bio-Rad, 
Hercules, CA, USA)과 그 사용방법에 따라 정량 한 다음 동량 의 Laemmli sample buffer (Bio-Rad)를 섞어서 sample을 만들 었다. 동량의 sample을 sodium dodecyl sulphate (SDS)-polyacrylamide gel을 이용하여 전기영동으로 분리한 후, PVDF membrane (Bio-Rad, USA)으로 electroblotting에 의해 전이시 켰다. 분리된 단백질이 전이된 PVDF membrane을 $5 \%$ skim milk를 처리하여 비특이적인 단백질들에 대한 blocking을 실 시하고 1 차 항체를 처리하여 상온에서 2 시간 이상 또는 $4^{\circ} \mathrm{C}$ 에 서 over night 시킨 다음 PBS-T로 세척(10분간 4번)하고 처리 된 1차 항체에 맞는 2 차 항체(PBS-T로 1:1,500으로 희석하여 사용)를 사용하여 상온에서 1 시간 정도 반응시켰다. 반응이 끝난 후 암실에서 enhanced chemiluminoesence (ECL) solution (Amersham Life Science Corp.)을 적용시킨 다음 X-ray film에 감광시켜 특정 단백질의 발현 양을 분석하였다.

\section{통계분석}

모든 실험 결과는 Statistical Package for the Social Sciences (SPSS) 통계 프로그램을 이용하여 평균(mean)표준편차(S.D.) 로 나타냈다. 각 실험군의 분석 항목별 통계의 유의성은 Duncan's multiple range test 를 이용하여 $p \times 0.05$ 수준에서 검증하 였다.

\section{결과 및 고찰}

\section{톳 분획물이 B16F10 세포 생존율에 미치는 영향}

톳 분획물의 농도에 따른 B16F10 mouse melanoma cells의 성장에 미치는 영향을 MTT assay로 분석한 결과는 Fig. 2와

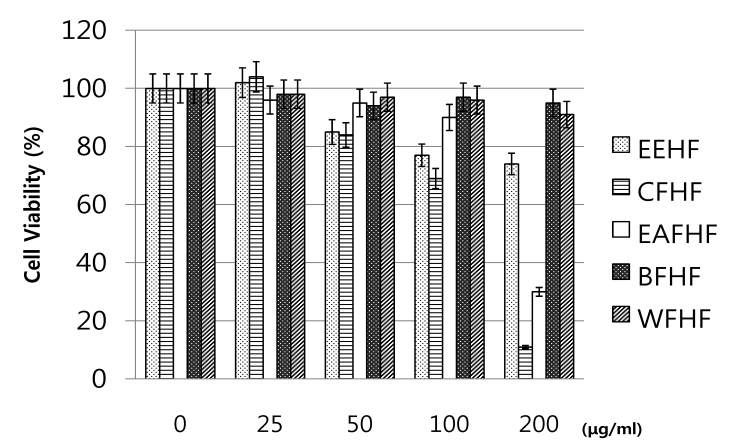

Fig. 2. Effects of various solvent fractions of Hizikia fusiforme on the cell viability in B16F10 melanoma cell by the MTT assay. B16F10 cells were cultured with various concentrations five types of ethanol extracts of Hizikia fusiforme (EEHF) and dichloromethane fractions of Hizikia fusiforme (CFHF) and ethyl acetate fractions of Hizikia fusiforme (EAFHF) and butanol fractions of Hizikia fusiforme (BFHF) and water fractions of Hizikia fusiforme (WFHF) for $72 \mathrm{hr}$. Data were expressed as percentage of control. Significant differences were determined by Duncan's multiple range test at $p<0.05$.
같다. MTT (3-(4,5-dimethylthiazol-2-yl)-2,5-diphenyl tetrazolium bromide) 분석은 탈수소 효소작용에 의해 노란색의 수용 성 기질인 MTT tetrazolium을 청자색의 formazan으로 환원 시키는 미토콘드리아의 능력을 이용하는 검사법으로 이 검사 법은 세포의 증식과 성장을 알아보는 대표적인 실험방법 중 하나로 살아있는 세포 수에 비례해서 흡광도를 나타낸다. 25 $200 \mu \mathrm{g} / \mathrm{ml}$ 의 농도에서 세포독성을 측정한 결과 $25 ~ 50 \mu \mathrm{g} / \mathrm{ml}$ 의 농도에서는 분획물 모두 $80 \%$ 이상의 생존율을 보였으나 $100 \mu \mathrm{g} / \mathrm{ml}$ 농도에서는 $\mathrm{EEHF}$ 처리군과 $\mathrm{CFHF}$ 처리군에서 $80 \%$ 이하의 생존율을 보였기 때문에 생존율 및 증식에 큰 영 향을 미치지 않는 $50 \mu \mathrm{g} / \mathrm{ml}$ 농도까지를 실험 조건으로 설정하 였다.

\section{멜라닌 색소 침착의 육안적 관찰}

톳 분획물과 a-MSH를 함께 처리하였을 때 육안적으로 멜 라닌 생성에 미치는 현상을 관찰한 결과는 Fig. 3에 나타내었 다. a-MSH를 처리하지 않았을 때에 비해 a-MSH를 처리하였 을 때 짙은 검은색으로 변화하는 것을 관찰할 수 있었고, 톳 분획물을 함께 처리하였을 경우 $\mathrm{BFHF}$ 처리군과 WFHF 처리 군을 제외한 나머지 분획물에서는 농도의존적으로 색이 옅어 짐을 관찰 할 수 있었다. 특히 $\mathrm{EEHF}$ 처리군과 $\mathrm{CFHF}$ 처리군의 $50 \mu \mathrm{g} / \mathrm{ml}$ 농도에서 두드러진 미백 효과를 관찰 할 수 있었다. $\mathrm{a}-\mathrm{MSH}$ 는 뇌하수체 중엽에서 분비되며 멜라닌세포에서만 발 현되는 막수용체인 MC1R (melanocortin 1 receptor)과 결합 하여 adenylyl cyclase를 활성화시키고, 세포 내 cAMP신호를 증폭시켜 protein kinase $\mathrm{A}(\mathrm{PKA})$ 의 활성화를 유도하며, 세포 내 cAMP response element binding protein (CREB)을 활성화 시킴으로써 멜라닌 세포에 특이적 전사인자인 microphthalmia-associated transcription factor (MITF)의 발현을 증가시킨다 $[1,4,5]$. MITF는 멜라닌 생성 효소인 tyrosinase와

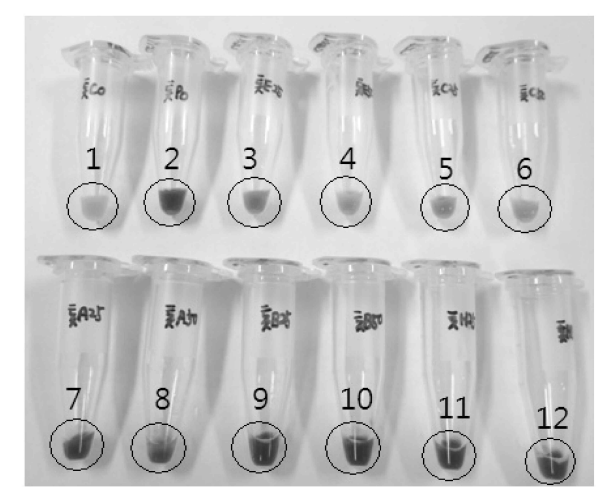

Fig. 3. The difference of melanin contents in B16F10 mouse melanoma cells treated with various solvent fractions of Hizikia fusiforme 1: control, 2: a-MSH, 3-4: a-MSH+EEHF, 5-6: a-MSH+CFHF, 7-8: a-MSH+EAFHF, 9-10: a-MSH+ BFHF, 11-12: a-MSH+WFHF (25, $50 \mu \mathrm{g} / \mathrm{ml}$, respectively). EEHF, CFHF, EAFHF, BFHF, EFHF refered to Fig. 2. 
TRP (tyrosinase related protein)의 발현을 자극하여, 멜라닌 세포의 멜라닌 생성을 조절하는 것으로 알려져 있다 $[2,8,23]$. 이 중에서 tyrosinase는 melanogenesis의 속도 결정 단계인 초기반응에 작용하는 효소로서, tyrosine을 3,4-dihydroxyphenylalanine (DOPA)로 전환하는 tyrosine hydroxylase활 성과 DOPA를 DOPA quinone으로 산화하는 DOPA oxidase 활성을 모두 가지고 있다. 따라서 멜라닌 생성의 주요 효소인 tyrosinase의 활성을 저해함으로써 멜라닌 생성을 억제시켜 미백 효과를 유도할 수 있다.

톳 분획물의 $a-M S H$ 자극에 의해 유도된 멜라닌 생성 억제 효과

멜라닌 합성 과정에서 핵심 역할을 하는 효소인 tyrosinase 의 활성을 톳 분획물을 농도별로 처리한 후 합성된 멜라닌 농도를 측정한 결과는 Fig. 4 와 같다. MTT 결과를 참고하여 멜라닌 생성량 측정 실험과 동일한 농도 범위에서 실험을 진 행하였다. 멜라닌 생성은 대조군에 비하여 a-MSH만 처리한 경우 뚜렷하게 증가하였고, 톳 분획물을 $25,50 \mu \mathrm{g} / \mathrm{ml}$ 의 농도 로 각각 처리한 결과 $\mathrm{BFHF}$ 처리군과 $\mathrm{WFHF}$ 처리군은 거의 변화가 없었으나 $\mathrm{EEHF}$ 처리군은 $25,50 \mu \mathrm{g} / \mathrm{ml}$ 농도에서 각각 $22.4 \%, 40.5 \%$ 감소되었고, $\mathrm{CFHF}$ 처리군은 $25,50 \mu \mathrm{gg} / \mathrm{ml}$ 농도 에서 각각 $14 \%, 33.2 \%$, EAFHF 처리군은 $25,50 \mu \mathrm{g} / \mathrm{ml}$ 농도에 서 각각 $18.8 \%, 31.5 \%$ 감소되어 농도의존적으로 억제되는 것 을 확인할 수 있었다.

Fig. 5에 나타난 tyrosinase 활성을 보면 톳 분획물을 25 ,

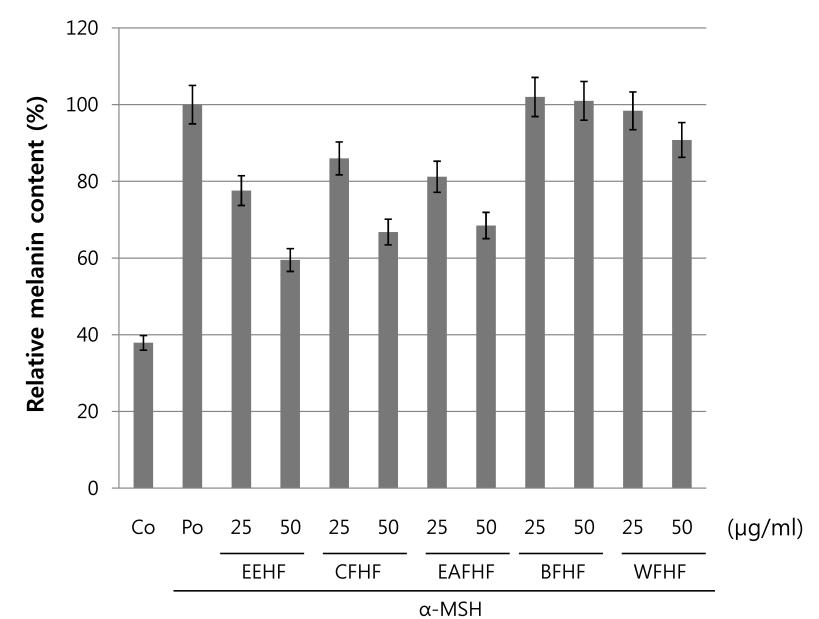

Fig. 4. Effects of various solvent fractions of Hizikia fusiforme on cellular melanin synthesis in B16F10 cells. Cells were treated with $200 \mathrm{nM}$ a-MSH in presence or absence of $\mathrm{EEHF}, \mathrm{CEHF}, \mathrm{EAEHF}, \mathrm{BEHF}$ and WEHF at the indicated concentrations for $72 \mathrm{hr}$. Melanin content was quantified by absorbance at $405 \mathrm{~nm}$. Co: Control without a-MSH, Po: Positive control with $200 \mathrm{nM}$ a-MSH. EEHF, CEHF, EAEHF, BEHF and WEHF refered to Fig. 2.

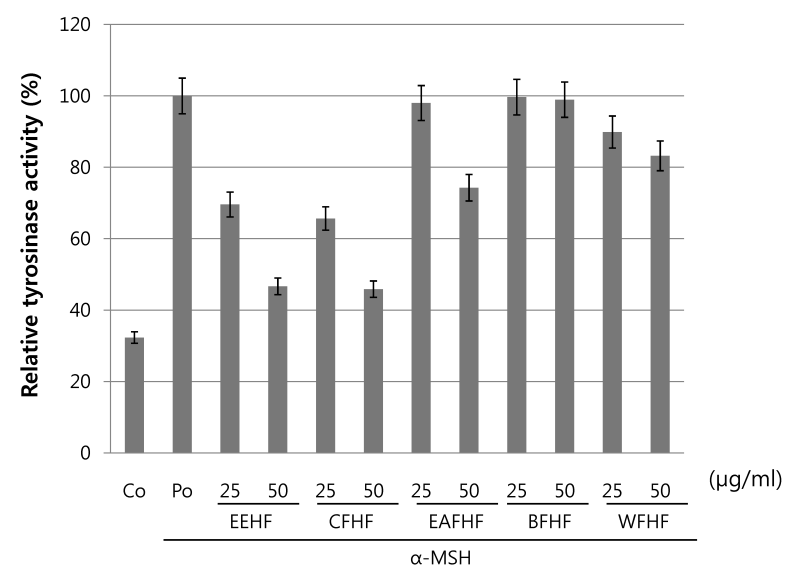

Fig. 5. Effects of various solvent fractions of Hizikia fusiforme on tyrosinase activity in B16F10 cells. Cells were treated with $200 \mathrm{nM}$ a-MSH in presence or absence of EEHF, CEHF, EAEHF, BEHF and WEHF at the indicated concentrations for $72 \mathrm{hr}$. Tyrosinase activity was measured by absorbance at $475 \mathrm{~nm}$. Co: Control without a-MSH, Po: Positive control with $200 \mathrm{nM}$ a-MSH. EEHF, CEHF, EAEHF, BEHF and WEHF refered to Fig. 2.

$50 \mu \mathrm{g} / \mathrm{ml}$ 의 농도로 각각 처리한 결과 BFHF 처리군은 거의 변화가 없었고 WFHF 처리군은 약간 감소하는 경향이 나타났 다. 이에 비해 $\mathrm{EEHF}$ 처리군은 $25,50 \mathrm{\mu g} / \mathrm{ml}$ 농도에서 각각 $30.4 \%, 53.3 \%$ 감소되었고, $\mathrm{CFHF}$ 처리군은 각각 $34.3 \%, 54.1 \%$ 감소되었다. 또한 EAFHF 처리군은 $25,50 \mu \mathrm{g} / \mathrm{ml}$ 농도에서 각각 $2 \%, 25.7 \%$ 감소되어, 농도의존적으로 억제시키는 것으로 나타났다. 따라서 톳 분획물 중 $\mathrm{EEHF}$ 처리군, $\mathrm{CFHF}$ 처리군 그리고 $\mathrm{EAFHF}$ 처리군은 $\mathrm{a}-\mathrm{MSH}$ 에 의해 유도 된 멜라닌 생성 과 tyrosinase 활성에 억제효과를 나타내는 것으로 보인다. 다 른 갈조류에 대한 연구에서 보면 Jeon 등의 연구[10]에서는 톳 에탄올 추출물은 $100 \mathrm{\mu g} / \mathrm{ml}$ 농도에서 음성대조군에 비해 통계적으로 유의하게 멜라닌 생성을 $26 \%$ 저해하는 것으로 보 고하였고 tyrosinase의 활성도 $40 \%$ 저해하는 것으로 보고하였 다. 감태에 대한 연구[6]에서는 감태 열수 추출물의 경우 10 $\mathrm{mg} / \mathrm{ml}$ 의 농도에서 $58 \%$ 의 tyrosinase 활성 저해 효능을 보고 한 바 있고, Park 등[20]의 연구에서는 B16F10 melanoma 세 포에서 다시마 열수추출물 처리 시 $1,10,100 \mu \mathrm{g} / \mathrm{ml}$ 농도에서 melanin 생성을 농도 의존적으로 억제 시켰다고 하였다.

\section{멜라닌 합성 관련 단백질의 발현량 변화 조사}

톳 분획물이 $\mathrm{a}-\mathrm{MSH}$ 자극에 의해 유도된 tyrosinase 활성과 멜라닌 생성을 억제 시키는 것을 확인하여 멜라닌 합성 관련 단백질 발현에 대한 영향을 확인하기 위하여 Western blot으 로 MITF, TRP1, TRP2, tyrosinase 발현을 조사한 결과는 Fig. 6과 같다. a-MSH을 단독 처리한 경우에 각 단백질의 발현이 현저하게 증가하는 것을 확인 할 수 있었고 반면 톳 분획물을 처리한 경우 $\mathrm{BFHF}$ 처리군과 $\mathrm{WFHF}$ 처리군을 제외한 $\mathrm{EEHF}$ 


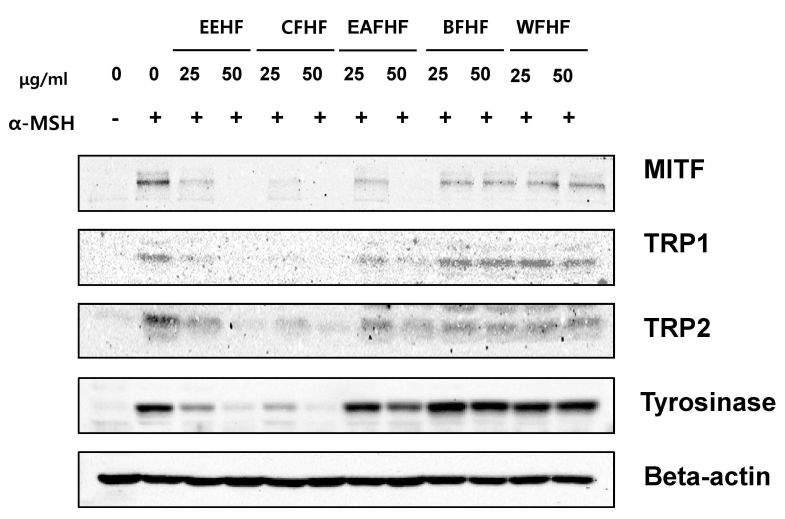

Fig. 6. Effects of various solvent fractions of Hizikia fusiforme on the levels of protein expression of MITF, TRP1, TRP2, Tyrosinase in B16F10 melanoma cells. Cells were treated with $200 \mathrm{nM}$ a-MSH in presence or absence of EEHF, CEHF, EAEHF, BEHF and WEHF. Cells were lysed and cellular proteins were separated by SDS-polyacrylamide gels and transferred onto PVDF membranes. The membranes were probed with the indicated antibodies. Proteins were visualized using an ECL detection system. $\beta$-actin was served as a loading control. EEHF, CEHF, EAEHF, BEHF and WEHF refered to Fig. 2.

처리군, $\mathrm{CFHF}$ 처리군, $\mathrm{EAFHF}$ 처리군에서 농도의존적으로 감 소하는 것으로 나타났으며 특히 $\mathrm{EEHF}$ 처리군과 $\mathrm{CFHF}$ 처리 군의 $50 \mu \mathrm{g} / \mathrm{ml}$ 의 농도에서는 매우 뚜렷하게 억제되어 앞의 실험들과 동일한 결과를 확인 할 수 있었다. 다른 갈조류의 미백효과에 대한 Yoon 등의 연구[25]에서 보면 B16F10 melanoma cell에서 미역쇠 추출물을 13-100 $\mu \mathrm{g} / \mathrm{ml}$ 농도까지 처리 하였을 때 TRP1, TRP2, tyrosinase, P-p38 등의 유전자 발현이 감소되었음을 보고한 바 있다. 또한 Yoon 등[24]은 제주조릿 대 잎 열수추출물이 a-MSH에 의한 세포신호전달 경로 중 지 속적인 ERK활성화를 저해함으로써 tyrosinase와 TRP-1의 발 현을 저해하는 활성을 가지고 있음을 보고하였고 Kim 등[11] 은 울릉도 곰취, 미역취, 삼나물 복합 추출물 및 bifidobacterium bifidum을 이용한 이들 발효 추출물은 멜라닌 합성에 직접적으 로 관여하는 효소인 tyrosinase 및 TRP-1, TRP-2의 발현을 억 제하여 melanin 합성을 억제한다고 보고하였다.

이상의 결과를 살펴볼 때 톳 분획물 중 특히 $\mathrm{EEHF}$ 처리군 과 $\mathrm{CFHF}$ 처리군이 B16F10 mouse melanoma cell에서 mela$\operatorname{nin}$ 생성에 관여하는 유전자인 MITF, TRP1, TRP2, tyrosinase 발현을 억제하므로 향후 미백 기능성 소재로서의 활용이 가능 할 것이라고 사료된다.

\section{감사의 글}

본 연구는 2012년 동의대학교 교내연구비(2012AA134) 지 원에 의해 수행되었습니다.

\section{References}

1. Bertolotto, C., Abbe, P., Hemesath, T. J., Bille, K., Fisher, D. E., Ortonne, J. P. and Ballotti, R. 1998. Microphthalmia gene product as a signal transducer in cAMP-induced differentiation of melanocytes. J Cell Biol 142, 827-835.

2. Bertolotto, C., Busca, R., Abbe, P., Bille, K., Aberdam, E., Ortonne, J. P. and Ballotti, R. 1998. Different cis-acting elements are involved in the regulation of TRP1 and TRP2 promoter activities by cyclic AMP: pivotal role of $\mathrm{M}$ boses (GTCATGTGCT) and of microphthalmia. Mol Cell Biol 18, 694-702.

3. Busca, R. and Ballotti, R. 2000. Cyclic AMP a key messenger in the regulation of skin pigmentation. Pigment Cell Res 13, 60-69.

4. Chakraborty, A. K., Funasaka, Y., Slominski, A. Ermak, G., Hwang, J., Pawelek, J. M. and Ichihashi, M. 1996. Production and release of proopiomelanocortin (POMC) derived peptides by human melanocytes and keratinocytes in culture: regulation by ultraviolet B. Biochim Biophys Acta 1313, 130-138.

5. Cheli, Y., Luciani, F., Khaled, M., Beuret, L., Bille, K., Gounon, P., Ortonne, J. P., Bertolotto, C. and Ballotti, R. 2009. Alpha-MSH and Cyclic AMP elevating agents control melanosome $\mathrm{pH}$ through a protein kinase A-independent mechanism. J Biol Chem 284, 18699-18706.

6. Cho, E. K. and Choi, Y. J. 2010. Physiological activities of hot water extracts from Ecklonia cava Kjellman. J Life Sci 20, 1675-1682.

7. Cho, K. J., Lee, Y. S. and Ryu, B. H. 1990. Antitumor effect and immunology activity of seaweeds toward sarcoma- 180 . $J$ Korean Fish Soc 23, 345-352.

8. Fuller, B. B., Lunsford, J. B. and Iman, D. S. 1987. Alpha-melanocyte-stimulating hormone regulation of tyrosinase in Cloudman S-91 mouse melanoma cell cultures. J Biol Chem 262, 4024-4033.

9. Hill, H. Z., Li, W., Xin, P. and Michell, D. L. 1997. Melanin: a two edged sword?. Pigment Cell Res 10, 158-161.

10. Jeon, M. H., Kim, M. H., Jang, H. J., Lee, S. W., Kim, J. H., Kim, H. S. and Lee, S. H. 2012. Whitening effect of Hizikia Fusiformis ethanol extract and its fractions. J Life SCi 22, 889-896.

11. Kim, D. H., An, B. J., Kim, S., Park, T. S., Park, G. H. and Son, J. H. 2011. Antimelanogenic effect of Ligularia fischeri, Solidago virga-aurea, Aruncus dioicus extracts from Ullung Island in murine melanoma cells. J Life Sci 21, 279-285.

12. Kim, D. M., Kim, K. H., Sung, N. Y., Jung, P. M., Kim, J. S., Kim, J. K., Kim, J. H., Choi, J. I., Song, B. S., Lee, J. W., Kim, J. K. and Yook, H. S. 2011. Effect of gamma irradiation on the extraction yield and whitening activity of polysaccharides from Undaria pinnatifida Sporophyll. J Korean Soc Food Sci Nutr 40, 712-716.

13. Kim, Y. M., Do, J. R., Kim, D. S. and Park, J. H. 2006. Cytotoxicities of hydrolyzed crude laminaran from Eisenia biscyclis on the SNU-1, Hela and SW cells. J Korean Food Sci Technol 38, 793-798. 
14. Kreiner, P. W., Gold, C. J., Keirns, J. J., Brock, W. A. and Bitensky, M. W. 1973. Hormonal control of melanocytes: MSH-sensitive adenyl cyclase in the Cloudman melanoma. Yale J Biol Med 46, 583-591.

15. Kwon, D. J., Lim, S. T., Chung, Y. J., Park, S. H. and Kweon, D. K. 2006. Comprehension and practical use of fucoidan extracted from prown sea weeds. Food Sci Ind 39, 73-80.

16. Oh, H. K. and Lim, H. S. 2007. Effects of the products of raw sea tangle on chronic idiopathic constipation. J Korean Soc Food Sci Nutr 36, 720-726.

17. Oh, K. L. 1997. Screening for the antioxidants from marine algae and separation of effective compounds from Hizikia fusiforme. Master dissertation, Cheju National University, Cheju, Korea.

18. Owen, T. A., Aronow, M. and Shahoub, V. 1990. Progressive development of the rat osteoblast phenotype in vitro relationships in expression of genes associated with osteoblast proliferation and differentiation during formation of the bone extracellular matrix. J Cell Physiol 143, 420-430.

19. Park, D. C., Ji, C. I., Kim, S. H. and Jung, K. J. 2000. Characteristics of tyrosinase extract from Ecklonia stolonifera. J Fish Sci Tech 3, 195-199.

20. Park, Y. J., Yoon, M. Y., Lim, H. W., Lee, J. Y., Kim, C. J. and Sim, S. S. 2004. Effect of hot-water extracts from Laminaria japonicus on melanin in B16 F10 melanoma cells.
J Pharm Soc Korea 48, 374-378.

21. Stroheker, T., Cabaton, N., Berges, R., Lamothe, V., Lhuguenot, J. C. and Chagnon, M. C. 2003. Influence of dietary soy isoflavones on the accessory sexorgans of the Wistar rat. Food Chem Toxicol 41, 1175-1183.

22. Tada, A., Suzuki, I., Im, S., Davis, M. B., Cornelius, J., Babcock, G., Nordlund, J. J. and Abdel-Malek, Z. A. 1998. Endothelin-1 is a paracrine growth factor that modulates melanogenesis of human melanocytes and participates in their responses to ultraviolet radiation. Cell Growth Differ 9, 575-584.

23. Yokoyama, K., Suzki, H., Yasumoto, K., Tomita, Y. and Shibahara, S. 1994. Molecular cloning and functional analysis of a cDNA coding for human DOPAchrome tautomerase/tyrosinase-related protein-2. Biochim Biophys Acta 1217, 317-321.

24. Yoon, H. S., Kim, J. K. and Kim, S. J. 2007. The inhibitory effect on the melanin synthesis in B16/F10 mouse melanoma cells by Sasa quelpaertensis leaf extract. J Life Sci 17, 873875 .

25. Yoon, H. S., Koh, W. B., Oh, Y. S.and Kim, I. J. 2009. The anti-melanogenic effects of Petalonia binghamia extracts in amelanocyte stimulating hormone-induced B16/F10 murine melanoma cells. J Korean Soc Appl Biol Chem 52, 564-567.

\section{초록 : 톳 분획물이 B16F10 흑색종 세포에서의 멜라닌합성에 미치는 영향 연구}

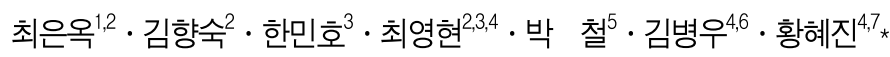

( ${ }^{1}$ 부산대학교 식품영양학과, 동의 대학교 ${ }^{2}$ 항노화연구소, ${ }^{3}$ 한의학과, ${ }^{4}$ 블루바이오소재개발센터, ${ }^{5}$ 분자생물학과, ${ }^{6}$ 생명응용학과, ${ }^{7}$ 식품영양학과)

본 연구에서는 톳 분획물의 미백효과 및 그에 따른 생화학적 기전의 해석을 위하여 톳 분획물이 a-MSH에 의해 인위적으로 유발된 melanogenesis 과정에 있어서 어떠한 영향을 미치는 지를 조사하였고, 이때 MITF, TRP1, TRP2, tyrosinase 등과 같은 melanin 생성에 관여하는 유전자들의 발현에 어떠한 변화가 유발되었는지를 조사하 였다. 톳 분획물 처리가 B16F10 mouse melanoma cell의 멜라닌의 생성량과 tyrosinase의 활성에 미치는 영향을 확인한 결과, butanol fraction (BFHF) 처리군과 water fraction (WFHF) 처리군을 제외한 ethyl extract (EEHF) 처 리군, dichlorimethane fraction ( $\mathrm{CFHF}$ ) 처리군, ethyl acetate fraction (EAFHF) 처리군 모두 농도의존적으로 멜라 닌 생성량과 tyrosinase 활성이 억제되었으며, MITF, TRP1, TRP2, tyrosinase의 발현이 단백질 수준에서 감소하였 음을 확인하였다. 그 중 특히 $\mathrm{EEHF}$ 처리군과 $\mathrm{CFHF}$ 처리군은 $50 \mu \mathrm{g} / \mathrm{ml}$ 의 농도에서 멜라닌 생성량을 $40.5 \%$, $33.2 \%$ 감소시켰으며, tyrosinase 활성도 $50 \mu \mathrm{g} / \mathrm{ml}$ 의 농도에서 각각 $53.3 \%, 54.1 \%$ 감소시켰다. 또한 EEHF, CFHF, EAFHF 처리군에서 MITF, TRP1, TRP2, tyrosinase의 발현이 농도 의존적으로 감소하였음을 확인하였다. 이상의 결과를 살펴볼 때 톳 분획물 중 특히 $\mathrm{EEHF}$ 처리군과 CFHF 처리군이 B16F10 mouse melanoma cell에서 melanin 생성에 관여하는 유전자인 MITF, TRP1, TRP2, tyrosinase 발현을 억제하므로 향후 미백 기능성 소재로서의 활용 이 가능할 것이라고 사료된다. 